\title{
WACANA RAKSASA RAHWANA DASAMUKA DALAM DI BAWAH BENDERA REVOLUSI
}

\author{
Edy Subali, Enie Hendrajati
}

\begin{abstract}
Abstrak
Artikel ini berjudul Wacana Raksasa Rahwana Dasamuka dalam "Dibawah Bendera Revolusi“. Bung Karno adalah presiden pertama Republik Indonesia yang produktif menulis atau mengarang. Bahasa yang dimanfaatkan dalam karangannya terikat konteks. Kata dan gaya bahasa yang digunakan dalam karangannya merupakan wujud aksi dan reaksi terhadap konteks kondisi sosial, ekonomi dan politik yang memprihatinkan sebagai akibat sistem ekonomi kapitalis yang dijalankan penguasa asing-Belanda.

Artikel ini bertujuan memberikan paparan faktual, obyektif dan ilmiah tentang "pemikiran, sikap dan gaya" Bung Karno dalam membahasakan raksasa Rahwana Dasamuka (selanjutnya disingkat $R R D$ ) dalam tulisantulisannya. Sampel yang dijadikan wilayah perburuan untuk memotret gaya membahasakan wacana RRD adalah teks-teks buah pikiran Bung Karno yang dikumpulkan menjadi satu buku dengan judul "Dibawah Bendera Revolusi“(DBR). Tulisan Bung Karno yang terhimpun dalam buku DBR berbentuk retorika persuasif. Wacana yang dimanfaatkan sebagai senjata persuasif antara lain adalah wacana RRD, simbol Kapitalisme, Imperialisme, dan Kolonialisme-Imperialisme. Wacana RRD digelar untuk membangun resistensi terhadap penjajah, yaitu pemerintahan asing-Belanda di Indonesia ketika itu.

Jenis kata yang dimanfaatkan untuk menghidupkan wacana RRD adalah kata benda, kata kerja, kata sifat, kata seru, kata bilangan dan kata ganti orang. Kata-kata yang berjenis apa pun dan dari ragam, bidang serta bahasa mana pun, selama fungsional-produktif untuk membangun struktur wacana (sistem makna atau cara pandang yang diinginkan) RRD cenderung dimanfaatkannya.

Dalam wacana RRD, Bung Karno dominan memanfaatkan metafor, seperti personifikasi, ironi, sinisme dan sarkasme. Gaya bahasa hiperpola, repetisi, erotesis dan antitesis pun dimanfaatkannya. Semua gaya bahasa tersebut dimanfaatkan untuk membangun struktur wacana Raksasa Rahwana Dasamuka. simbol kejahatan dan keserakahan yang harus ditumpas. Dengan pilihan kata dan gaya bahasa tersebut, Bung Karno seperti menyediakan cara membaca, dan cara menyikapi RRD sebagai jelmaan kapitalis-imperialis. Pikiran, sikap dan perilaku gemas, dongkol dan garang pembaca seperti dibentuk dan dirahkan ke "buto" Raksasa Rahwana Dasamuka simbol keserakahan dan kejahatan.
\end{abstract}

Kata kunci: Raksasa Rahwana Dasamuka, retorika persuasif, konteks, metafor, wacana.

Dibawah Bendera Revolusi (DBR) merupakan judul kumpulan teks atau wacana buah pikiran Bung Karno. Di dalamnya terdapat 60 teks dengan judul dan topik beragam, dari masalah Nasakom, Kapitalisme-Imperialisme hingga teks 
tulisannya yang berjudul Kuasanya Kerongkongan. Bung Karno aktif berkomunikasi kepada publik pada masa pemerintahan asing-Belanda bukan sematamata karena gemar berbahasa (berpidato atau mengarang), tetapi juga karena faktor konteks situasi dan kondisi sosial dan ekonomi masyarakat kita yang ketika itu berada dalam keadaan terjajah dan ingin lepas merdeka dari penjajahan Belanda. Pernyataan berikut ini dapat menjadi dasar atau indikator bahwa wacana dan bahasa Bung Karno terikat konteks keterjadian.

Bung Karno gemar mengarang dan kemudian datanglah zaman yang dalam sejarah kehidupan Bung Karno dapat dianggap masa pencurahan pikiran dalam karang-mengarang, yaitu semasa Bung Karno bersama-sama dengan kawan sefaham beliau mendirikan dan menggerakkan Partai Nasional Indonesia (PNI) dan Partai Indonesia (Partindo) serta semasa beliau diasingkan ke Endeh dan akhirnya ke Bengkulen. Pada zaman penjajahan untuk menyimpan buah pikiran para pemimpin pergerakan terutama buah pena Bung Karno, baik yang berupa karangan maupun yang berupa pidatopidato diperlukan keberanian bagi para penyimpannya (DBR:1964).

Pernyataan tersebut mengisyaratkan bahwa wacana dan bahasa Bung Karno merupakan aksi dan reaksi terhadap konteks. Oleh karenanya pertanyaan yang diperlukan adalah apa kecenderungan motif dan tujuan Bung Karno menggelar wacana RRD? Bagaimana bentuk, rupa, dan perangai bahasa, terutama pilihan kata dan gaya bahasanya dalam wacana RRD?

Bahasa dan wacana yang digelar dan terhimpun dalam DBR merupakan dokumen sejarah yang pernah bertugas nyata dalam tindak komunikasi pada jaman pemerintahan asing-Belanda menguasai bumi Nusantara. Wacana dan bahasa yang digunakan mencerminkan aksi dan reaksi terhadap konteks keterjadian. Berarti, wacana RRD dibangun dengan bahasa yang lebih diarahkan pada fungsi komunikasi persuasif. Bagaimana bahasa dalam wacana RRD dapat membangun struktur wacana bahwa RRD adalah sebagai simbol penjajahan, keserakahan dan harus diusir dari bumi Nusantara. Penggunaan bahasanya seperti tindakan provokatif-persuasif dan cenderung tanpa dikendala oleh sistem formal tatabahasa. Hymes (Purwo, 1989:49) memperjelas dengan pernyataan, “justru yang lebih penting dipertimbangkan dalam bahasa dan berbahasa adalah kecocokan (appropriateness) penggunaan suatu tuturan pada konteks sosiokulturalnya, bukan sekedar kegramatikalan.” Dengan pesan yang serupa, Firth (Djajasudarma, 1994:1) 
mempertegas dengan mengatakan, "konteks situasi perlu diteliti karena studi bahasa dan kerja bahasa ada pada konteks."

Pernyataan-pernyataan tersebut berimplikasi bahwa fungsi komunikasi dapat diungkapkan dengan beberapa cara, gaya dan satuan lingual. Sebaliknya, satu satuan lingual atau pernyataan dapat digunakan untuk menjalankan beberapa fungsi komunikasi. Kepekaan terhadap konteks dapat memperkaya strategi berbahasa. Demikian juga pendengar/pembaca/petutur, jika mereka peka konteks dapat memahami makna dan maksud penggunaan bahasanya dengan mudah. Soenjono Dardjowidjojo (PELLBA 4, 1991:73) dalam paparannya tentang pemerolehan semantik pada anak menyatakan, "pemerolehan makna pada anak banyak ditentukan oleh kematangan daya kognitif dan lingkungan. Proses menuju ke kedewasaan menambah kemampuan untuk mengamati dan menyerap fenomena alam sekitar; lingkungan memberikan bahan masukan untuk mengelompokkan atau memilahmilah satu fenomena dari yang lain.” Mengutip pendapat Will Durant, Jalaluddin Rakhmad (1992:10) menyatakan

"Calon orator harus mempelajari musik supaya ia memiliki telinga yang mendengarkan harmoni; tarian, supaya memiliki keanggunan dan ritme; drama untuk mnghidupkan gerakan dan tindakan; sastra untuk membentuk gaya dan melatih memorinya; sains, untuk memperkenalkan dia dengan pemahaman mengenai alam; filsafat, untuk membentuk karakternya berdasarkan petunjuk akal....

Memahami bahasa yang terikat konteks tempat, waktu dan tujuan, seperti bahasa Bung Karno bisa dianalogikan dengan narasi Seribu Satu Malam. Bung Karno dengan memanfaatkan potensi bahasa yang tidak terbatas, ia berusaha menggali, memanipulasi dan memfungsikan potensi kekuatan bahasa dengan harapan dapat menciptakan ruang-ruang untuk mengartikulasikan serta mengaktualisasikan fantasi, imajinasi dan mimpi-mimpi yang mampu membebaskan masyarakat majemuk terjajah dari penjajahan, penderitaan, bahkan kematiannya.

\section{Wawasan Teoretis}

Pragmatik memperlakukan bahasa tidak terpisah dari konteks keterjadian. Konteks keterjadianlah yang memprovokasi pilihan bahasa. Bahasa mengemban 
tugas untuk melakukan tindakan tertentu secara efektif. Tugasnya bergantung pada konteks, yang oleh Halliday (Tou, 1992: 16) disebut medan wacana. Konteks menentukan pilihan bahasa, gaya bahasa dan strategi berbahasa. Dengan demikian konteks keterjadian menjadikan bahasa seperti bola dalam pertandingan sepak bola. Bahasa sebagai bola yang dipermainkan oleh para pemain. Bahasa sebagai bola tidak dapat diprediksi maknanya sebelum dipermainkan dalam konteks atau medan wacana. Meskipun bola bahasa tersebut bermakna, tetapi maknanya bersifat formal atau makna dalam ranah semantik.

Menggunakan bahasa berarti seperti bermain sepak bola, memerlukan pemain dan cenderung melibatkan publik. Masing-masing pemain, termasuk publik cenderung memiliki pengetahuan bersama, apa dan bagaimana bermain dan memainkan bola bahasa. Dari perspektif semiotik, segala yang berada dalam lingkungan permainan, termasuk para partisipan adalah tanda yang dapat mengirim informasi. Ada sinyal atau simtom yang membuat mereka mengerti, meskipun pengertian tersebut harus diperoleh melalui kepekaan menginterpretasinya. Hal tersebut karena tidak semua tanda merupakan konvensi atau simbol dan ikon, tetapi dapat juga berupa indeks. Dengan demikian memahami bola bahasa berarti memerlukan interpretasi terhadap konteks situasi dan kondisi yang menjadi sumber dan motivasi dalam memilih dan menggunakan bahasa dan gaya bahasanya.

Bahasa bersifat tidak terbatas dan lentur, seperti halnya bola. la dapat dipermainkan dengan berbagai cara. Strategi dan teknik atau gaya mempermainkan bola bahasa ditentukan oleh konteksnya. Kata kamu, saudara, anda, engkau dan semacamnya dari perspektif pendekatan formal dan semantik bersinonim, tetapi dari perspektif pragmatik berbeda. Masing-masing bernuansa berbeda dan memiliki fungsi tersendiri sesuai dengan konteksnya. Pragmatik menentukan stilistik karena menyangkut prinsip-prinsip kerja sama atau kecocokan dengan konteksnya. Retorika memanfaatkan konteks dalam memilih dan memanipulasi potensi bahasa tersebut untuk mencetak atau memperoleh gol kemenangan. Para pemain sesuai dengan status, posisi dan konteksnya pasti memilih dan menampilkan teknik dan gaya mempermainkan bola bahasa agar efektif untuk tujuan memenangkan pertandingan. Penggunaan kata dan gaya dalam retorika cenderung merupakan pilihan yang 
mengandung tenaga makna tertentu sehingga dapat memenangkan pertadingan. Dengan teknik dan gaya mempermainkan bola bahasa, publik bukan hanya senang dan mengerti, tetapi dapat terpengaruh dan dipengaruhi.

Bahasa dari perspektifi pragmatik bukan hanya sebagai media netral, seperti bola dalam permainan sepak bola. Ia memang bukan tujuan, tetapi media yang di dalamnya bermuatan tujuan. Oleh karena itu, bola bahasa tidak bermakna pada dirinya sendiri. Makna ada pada subyek pemain. Para pemainlah (penulis atau pembicara) yang merencanakan dan menentukan tujuan sesuai dengan motifnya. Jika tujuan menggelar wacana RRD untuk memecahkan masalah, misalnya merajut kekuatan untuk mengusir penjajah maka struktur wacana RRD dibangun dengan bahasa dan gaya bahasa yang berdaya dalam menggugah afeksi dan psikomotor khalayak pembaca atau pendengarnya. Penulis atau pembicara akan bersikap dan bertindak seperi pemain bola dalam pertandingan sepak bola. Bola bahasa yang dipermainkan selain mempertimbangkan konteks tempat dan waktu juga strategi dan kelihaian mengolah bola bahasa yang dapat memperlancar gerakan bola menuju tujuan akhir, yaitu keberhasilan memecahkan masalah.

Konteks keterjadian, wacana dan bahasa cenderung tidak terpisah. Bagi seorang komunikator, seperti orator, wacana dan bahasa adalah causa sine qua non. Oleh karena wacana selalu berupa atau berwujud bahasa maka antara ketiganya berhubungan secara fungsional.

Berbahasa sebagai kegiatan bertindak dengan dan dalam bahasa. Berbahasa bukan seperti orang mengigau, tanpa sadar dan kosong tujuan. Tujuan utamanya adalah memecahkan masalah. Konsekuensinya struktur wacana dibangun dengan memanfaatkan kata-kata dan gaya bahasa yang berdaya dalam melakukan tidakan memecahkan masalah. Oleh karena itu timbul terminologi "retorika argumentasi, retorika persuasi, retorika narasi sugesti dan retorika deskripsi sugesti” (Keraf, 1992:99-120). Retorika persuasi memiliki tipe "retorika penalaran, retorika oposisi dan retorika aksi; tujuan retorika persuasi ialah mengubah, membentuk atau memperkuat tanggapan atau respon” (Malik dan Iriantara, 1994:146-160).

Leech, seperti yang dipaparkan Oka (1993:22) menjelaskan bahwa berkomunikasi merupakan "seni ketrampilan menggunakan bahasa yang lebih resmi 
dan terencana, memusatkan diri pada situasi ujar dan berorientasi pada tujuan persuasif atau efek tertentu pada pembaca/pendengarnya." Sebutan "situasi ujar" dan "orientasi tujuan" menunjukkan bahwa retorika berindikasi sebagai fenomena wacana dan pragmatik.

Pragmatik dan wacana tampaknya tidak terpisah karena keduanya sama-sama melibatkan konteks dan bahasa. Dalam PELLBA 6 Dede Otomo menyebutkan bahwa memang ada yang menyamakan antara pragmatik dan wacana. Ia sendiri dengan berpegang pada tulisannya Stephen Levinson berpendapat bahwa pragmatik hanya berbicara mengenai analisis percakapan atau interaksi lisan, bukan teks tertulis sehingga ia menganggap pragmatik termasuk di bawah analisis wacana. Meskipun demikian, ia menyadari bahwa setiap buku mempunyai sudut pandang yang tersendiri (Purwo, 1993:19).

Perbedaan pandangan tentang pragmatik dan wacana, termasuk antara wacana dan teks tidak akan mengingkari kenyataan bahwa antara retorika, pragmatik, wacana dan teks saling berkaitan. Secara singkat, retorika merupakan pengartikulasian pragmatik, wacana, bahkan teks. Retorika menyampaikan makna, tetapi makna yang terikat konteks atau situasi ujar. Berarti retorika bermotif dan bertujuan melakukan tindakan dengan bahasa kepada pembaca atau pendengarnya. Jika wacana dipahami sebagai "aktivitas sharing (saling berbagi dan tukar menukar) pendapat ataupun pemikiran untuk memperkaya wawasan dan pemikiran dalam rangka mencari kebenaran yang lebih tinggi” (Hidayat, 1996:130) maka retorika dapat dikatakan sebagai seni dan praktik wacana. Demikian pula jika teks dimaknai sebagai "bahasa yang sedang melaksanakan tugas tertentu dalam konteks situasi" (Halliday dalam Tou, 1992 : 13) maka retorika berarti praktik berbahasa, praktik wacana dan praktik budaya. Oleh karena retorika cenderung bermotif untuk mencapai tujuan pemecahan masalah maka retorika dapat berupa teks atau wacana sebagai proses, teknik, perilaku atau tindakan tertentu. Dengan pemahaman tersebut maka pengertian teks dan wacana sulit dibedakan atau bahkan sama. Retorika dengan pendekatan pragmatik berarti praktik wacana atau teks dengan status sebagai subyek. Retorika memilih dan memanfaatkan wacana dan bahasa sebagai subyek bukan sebagai obyek atau hasil. 
Retorika menjadikan bahasa dan wacana berperan sebagai subyek untuk melakukan tindakan persuasi yang berdaya dalam membangun, menghidupi, menyegarkan dan mensosialisasikan makna-makna sosial tertentu sesuai dengan konteks situasi dan kondisi. Yang dimaksud makna-makna sosial di sini adalah makna intensional atau yang oleh Noeng Muhadjir "apa yang di belakang penampakan” (Hery, 2002:218). Dengan demikian retorika dapat berupa wacana atau teks. Sebagai wacana atau teks maka ia merupakan contoh kegiatan atau tindakan memproses makna sosial dalam konteks situasi dan kondisi tertentu dan untuk tujuan tertentu. Konteks situasi dan kondisi tersebut analog dengan ruang tempat memproses satuan makna sosial digelar, difiksasi, dilembagakan atau dipadatkan dalam wacana atau teks. Teks adalah "any discourse fixed by writing", kata Ricoeur (Hery, 2002:217).

Andrik Purwasito dalam bukunya "Imajeri India Studi Tanda dalam Wacana (2002:477) (pengembangan disertasinya) menemukan konklusi refleksi teoretis, “"wacana merupakan senjata perang dengan cara lain.” Jenius lokal melakukan komunikasi politik dengan menggunakan wacana Ahimsa, nonkooperasi, Dasamuka, Aji saka, Styagraha, berdikari (swadesi) dan lain sebagainya. Wacana dengan representasi ruh India dapat berfungsi membangun spirit dan partisipasi politik, baik resistensial maupun semangat kebangsaan dan identitas karena pesan-pesan politik dalam wacana dapat berefek snowball dalam masyarakat.

Andrik Purwasito dalam disertasinya yang dikembangkan tersebut melakukan analisis wacana dengan menggunakan pendekatan sejarah intelektual dan sosiologis. Data-data wacana dianalisis dengan "interpretasi akal sehat" ala Glifford Geertz dengan bantuan semiotika pragmatik. Jika wacana dapat menjadi senjata membangun pendidikan, partisipasi dan tindakan politik dalam masa kolonial maka peran retorika tentu sangat signifikan karena retorika dengan gaya dan daya bahasanya yang berperan sebagai subyek dapat melakukan praktik wacana. Dengan kata lain, retorika yang menghidupi, menyegarkan dan mendistribusikan wacana, baik wacana resistensi maupun wacana kebangsaan. Analisis wacana, akhirnya dapat berupa analisis kritis terhadap bahasa dan cara bahasa tersebut dalam melakukan tindakan politik dalam konteks waktu dan tempat tertentu. 
Berdasar pemahaman tersebut maka wacana Kapitalisme dan Imperialisme dalam setting sosial dan politik diskriminatif dapat disegarkan hidupnya melalui retorika atau praktik wacana. Retorika dapat dibangun dengan bahasa yang cenderung mencerminkan motif, tujuan atau konteks jamannya. Bahasa dan wacana yang digelar berperan sebagai seperangkat teknik dan proses kreatif yang dinamis sesuai dengan konteks situasi dalam mengekspresikan makna dan maksud tertentu.

Analisis terhadap linguistik yang melibatkan pertimbangan kontektual, semestinya termasuk bidang penyelidikan bahasa yang disebut pragmatik" (Brown dan Yule dalam Soetikno, 1996:26). Akhirnya, bahasa dan wacana yang digelar dalam retorika tidak bisa dipandang sebagai mekanisme internal bahasa yang terlepas dari konteks. Retorika bukan penggunaan bahasa dan wacana dalam ruang kosong untuk tujuan kosong. Mengutip pendapat Guy Cook, Eriyanto (2001:9) memaparkan bahwa "pengertian wacana meliputi teks, konteks dan wacana". Berarti, wacana berhubungan dengan pragmatik melalui bahasa/retorika/teks dan konteks. Yang dimaksud konteks adalah unsur luar bahasa yang mempengaruhi pemakaian bahasa. Dell Hymes (Dan Nimmo, 1993:91) menyebutkan jenis konteks yang dapat mempengaruhi makna dan pemakaian bahasa, yaitu setting/scene 'tempat atau suasana', participants, ends, act sequences, urutan tindak atau amanat, keys 'cara atau nada', instrumentalities sarana", norms, dan genres, 'ragam', disingkat SPEAKING.

Retorika dapat beroperasi dalam konteks pemerintahan dengan setting dan realitas politik yang tidak memihak kepada masyarakat banyak. Sistem politik dapat memberi peluang bagi merembesnya sistem ekonomi kapitalis yang mengakibatkan keadaan ekonomi dan sosial masyarakat memprihatinkan. Konteks tersebut dapat melakhirkan politik wacana. Dalam arti, retorika dapat membangun struktur wacana politik dan sosial yang dapat menyegarkan ingatan publik terhadap suatu sistem nilai tertentu untuk tujuan tertentu. Wacana bunga bank, haram dan mencekek misalnya, dapat disegarkan atau diwacanakan dengan retorika untuk tujuan politis. Wacana Kapitalisme-Imperialisme disegarkan keberadaan dan perilakunya dengan retorika, yakni pemakaian bahasa yang dapat menanamkan pengetahuan, definisi kepada khalayak sesuai dengan versi dan tujuannya. Retorika dengan mamanfaatkan wacana 
dengan tema tertentu dapat membangun struktur wacana yang akhirnya berfungsi sebagai sistem makna, sistem cara pandang tertentu, skema interpretasi, singkatnya paradigma. Retorika dengan menggelar wacana dengan tema tertentu berarti dapat menggiring bahkan mendikte pikiran, emosi dan tindakan pembaca atau pendengar ke arah sistem cara memandang dan cara menyikapi sesuatu dengan cara tententu. Hal tersebut dapat dilakukan karena wacana dan persepsi, memori, ilusi dan imaginasi cenderung berhubungan. Retorika menyegarkan wacana dengan tema tertentu dapat menggugah memori, ingatan, ilusi dan imaginasi publik. Membangun opini publik dapat dilakukan dengan memanfaatkan wacana tertentu sebagai tema retorika. Halliday memperjelas dengan mengatakan bahwa wacana atau teks sebenarnya sebagai satuan makna yang diungkapkan, dikodekan agar dapat dikomunikasikan. Dengan demikian teks atau wacana tidak dapat diberi batasan seperti sejenis kalimat; tidak begitu saja memperlakukan teori teks atau wacana sebagai perpanjangan teori tatabahasa atau sistem-sistem formal (Tou, 1992:14).

Retorika dan wacana berhubungan. Yang menghubungkan adalah konteks. Konteks yang memotivasi (akhirnya bentuk retorika dan wacana. Dalam konteks sistem politik yang tidak demokratis, retorika dapat memanfaatkan potensi bahasa sebagai ruang dan tindakan untuk menggelar wacana tertentu, yang diarahkan untuk menghidupi dan menyegarkan memori dan persepsi publik, misalnya akan kejayaan masa lalu, kesengsaraan masa kini sebagai akibat sistem politik yang tidak demokratis dan membangun harapan baru ke depan. Ketiganya dapat dipecahkan dengan menggunakan senjata praktik wacana.

\section{Pembahasan}

Melalui teks dalam buku Dibawah Bendera Revolusi, Bung Karno melakukan perlawanan persuasif dengan taktik linguistik terhadap ideologi Liberalisme dan sistem ekonomi Kapitalisme. Sistem tersebut dikategorikan menyuburkan Imperialisme dan Kolonialisme. Dalam DBR, tema yang menjadi fokus praktik wacana dengan nuansa bahasa emosional-persuasif adalah tema Kapitalisme dan Imperialisme. Dengan tema tersebut Bung Karno akan membangun 
struktur wacana RRD ke memori publik terjajah dengan tujuan melepaskan diri dari penjajahan asing-Belanda di Indonesia.

Mengapa wacana RRD yang diandalkan Bung Karno untuk membangun masyarakat baru (nation building dan character building) yang dapat melepaskan diri dari kolonialisme dan imperialism? Masyarakat terjajah (terutama suku Jawa) pada masa pemerintahan asing-Belanda tentu tidak asing dengan seni pewayangan. Rahwana dalam seni pewayangan dilukiskan sebagai raksasa yang memiliki sepuluh kepala (dasa berarti sepuluh, muka berarti wajah), sepuluh leher (dasagriva) dan berkerongkongan sepuluh (dasakanta). Ia juga memiliki dua puluh tangan. Bahasa tubuh Rahwana merupakan simbol kesombongan, kemauan yang tak terbatas atau keserakahan. Rahwana adalah simbol keserakahan terhadap tahta, harta dan wanita. Masyarakat terjajah dari lapisan bawah sampai atas cenderung mengerti siapa dan bagaimana watak dan tindakan Rahwana dalam seni pewayanga. Pengertian dan pemahaman tentang sifat-sifat Rahwana yang sudah ada dalam memori publik atau rakyat terjajah itulah yang digugah, dihidupkan dan dipertontonkan kepada mereka dengan cara menganalogikannya dengan Liberalisme-Kapitalisme. Rakyat terjajah diajak melihat dan menyikapi perilaku sistem ekonomi kapitalis yang ekuivalen dengan RRD.

Bentuk kata yang dimanfaatkan membangun struktur wacana RRD adalah yang secara pragmatik fungsional-efektif dan produktif dalam melakukan tindakan menata ulang persepsi, sikap dan tindakan pembacanya sebagai bekal melakukan perlawanan tehadap Imperialisme dan membangun masa depannya yang merdeka dan berdaulat. Berikut ini contoh bahasa Bung Karno yang pernah bertugas melakukan praktik wacana dalam konteks pemerintahan asing-Belanda di Indonesia.

(1) a. Raksasa -"biasa" jang dulu berdjengkelitan di atas padang keredjekian Indonesia, kini mendjadi Raksasa Rahwana Dasamuka jang bermulut sepuluh (DBR, 1964:264).

b. Imperialisme jang menghinggapinja makin lama makin bersulur, berakar, melancar-lancarkan tangannja kekanan dan kekiri dan ke belakang dan ke depan, melebar, mendalam dan ke kiri, ke belakang dan ke depan, melebar, mendalam, meliputi dan menjerapi tiap-tiap bagian daripada masjarakat jang sakit (DBR, 1864:261).

c. Imperialisme raksasa itulah jang menggetarkan bumi Indonesia dengan 
djedjaknja jang seberat gempa, menggetarkan udara Indonesia dengan guruh suaranja jang sebagai guntur mengaut-aut di padang kerezekian negeri dan rakjat Indonesia (DBR, 1964:261).

d. Tidakkah kaum Marhaen sampai kini masih bongkok punggungnja diduduki oleh kapitalis jang mengengkel-engkel mereka, mengentrokentrok mereka, memperbudakkan mereka, memperb $\mathrm{i} n$ at angkati mereka sampai kedasar-dasarnja neraka kesengsaraan dan neraka kelaparan (DBR, 1964:287).

Diksi, kalimat dan gaya bahasa kutipan tersebut mendeskripsi, menghidupkan dan memperlihatkan ke rakyat terjajah tentang kelakukan RRD alias Liberalisme-Kapitalisme. Penggunaan bentuk-bentuk kata dalam kutipan itu merupakan prototipe strategi linguistik dalam mengartikulasikan dan mengaplikasikan sikap Bung Karno terhadap sistem ekonomi kapitalis yang dijalankan oleh elit pemerintah asing-Belanda.

Bung Karno tidak bertutur tentang Liberalisme-Kapitalisme, tetapi simbolisasinya, yaitu Raksasa Rahwana Dasamuka jang bermulut sepuluh; makin bersulur, berakar, melancar-lancarkan tangannja kekanan dan kekiri dan ke belakang dan ke depan; kaum Marhaen sampai kini masih bongkok punggungnja diduduki oleh kapitalis jang mengengkel-engkel mereka, mengentrok-entrok mereka. Informasi apa yang ditunjukkan dan dapat dipahami dengan penggunaan kata yang "berwajah" seperti itu? Jawabannya tergantung pada paradigmanya, formalstruktural atau fungsional-kontekstual pragmatik. Dari perspektif formal-struktural, kata tersebut memberikan informasi berikut ini.

Pertama, kata tersebut berwujud kata asal/dasar, misalnya gempa, udara; berkonstruksi kata majemuk, seperti Raksasa Rahwana Dasamuka yang bermulud sepuluh, padang kerezekian, neraka kelaparan; berkonstruksi frase benda, seperti masyarakat yang sakit, kaum Marhaen. Dari segi semantik kata benda tersebut mengandung ciri makna (komponen makna) spesifik atau kongkret karena mengacu kepada benda, hidup, bernyawa, menyerupai manusia, bertubuh besar, tinggi serta bermulut sepuluh. Kata-kata benda tersebut mengacu dan berkolokasi kepada nama makhluk raksasa "buta," yaitu Raksasa Rahwana Dasamuka. Makhluk raksasa tersebut direpresentasikan seperti lukisan atau potret yang dapat memberikan bayangan sensasi hidup sehingga dapat menjadi stimuli kongkret bagi pembaca atau 
pendengarnya, terutama yang paham dunia pewayangan. Dengan penggunaan kata seperti itu maka pembaca seperti diajak melihat postur tubuhnya yang besar dan tinggi, diajak melihat gestur atau gerakan tangannya, matanya, kakinya, mulurnya yang sepuluh ketika menyantap makanan. Pembaca juga seperti diajak merasakan jejak kakinya yang bisa mengetarkan dan menggoncangkan bumi; pembaca seperti diajak mendengar nada dan volume suaranya yang menggelegar, menderu-deru serta berdentuman. Penggunaan kata yang "serupa" dengan gambar atau lukisan tersebut dapat dipahami sebagai simtom bahkan sinyal bahwa retorika bahasa Bung Karno memanfaatkan bahasa gambar, lukisan atau pencitraan. Jadi, muka, mulut, leher dan tangan Rakrasa Rawana yang berjumlah sepuluh itu seperti analog dengan investasi negara-nagara asing di Indonesia, baik di tambang maupun di pertanian. Para investor asing yang datang dari beberapa negara itu oleh Bung Karno diibaratkan sebagai mulut-mulut RRD. Mereka makin bersulur, berakar, melancar-lancarkan tangannja kekanan dan kekiri dan ke belakang dan ke depan; kaum Marhaen sampai kini masih bongkok punggungnja diduduki oleh kapitalis jang mengengkelengkel mereka, mengentrok-entrok mereka.

Frekuensi pemakaian kata yang mencitrakan dalam bahasa Bung Karno relatif produktif. Tidak sulit mengidentifikasi bentuk-bentuk kata yang mencitrakan benda hidup, bernyawa, misalnya manusia, binatang, tumbuhan maupun benda mati, seperti yang bersangkut-paut dengan matahari, lautan, bumi, gempa, guntur, air, baja, besi, batu hitam dan lain sebagainya. Kutipan berikut ini terdapat contoh kata yang menggambarkan kondisi masyarakat majemuk dalam konteks sistem ekonomi RRD simbol Liberalisme-Kapitalisme.

(2) a. Pertempuran antara feodalisme kuno dengan feodalisme baru membikin badan masjarakat demam, kurang tenaga. Memang masjarakat intransformatie, berganti bulu, mlungsungi seolah-olah demam, abnormal (DBR, 1964:260).

b. Rakjat Indonesia jang sediakala terkenal gagah berani, tak gampanggampang suka tunduk, jang perahunja melintasi lautan dan samudra ... kini mendjadilah rakjat jang lemah budi, rakjat jang hilang kepercajaannja pada diri sendiri, hilang kepribadiannya, hilang kegagahannja, hilang ketabahannya, semangat harimau ... sudah mendjadi semangat kambing jang lunak, pengecut, selamanya harus dipimpin dan dituntun (DBR, 1964:276). $100 \%$ mendjadi rakjat 
kambing, kita kaum beroch budak, kita banjak jang djadi pendjual bangsa, hilang sama sekali kelaki-lakian kita ... (DBR 1964: 277) Bentjana bathim (DBR, 1964:276); kerusakan bathin (DBR, 1964:275).

c. ... masjarakat sakit kedatangan masjarakat gagah perkasa, masjarakat jang sakit tidak berkesempatan sembuh, makin lama makin sakit, makin habis tenaganja, makin habis semua kutu-kutunja (DBR, 1964:261).

d. ... dari zaman compagnie sampai sesudah compagnie, dari zaman cultuurstelsel sampai kezaman modern-imperialisme, tiap-tiap "kutu" kita dipitas dan dibunuh (DBR, 1964:151).

e. Tetapi imperialisme ... makin bersulur, berakar (DBR, 1964:261). ... bukan saja berganti besarnja, tetapi juga berganti wujudnja, berganti sifatnja, berganti tiranya, berganti sepak-terdjangnja, berganti wataknja, jang tak berganti kehausannja mentjari rezeki (DBR, 1964:262).

f. Imperialisme anaknja kapitalisme. Kapitalisme tua belum kenal pabrikpabrik sebagai sekarang, belum kenal industri-industri sebagai sekarang. Belum kenal bank-bank sebagai sekarang, belum kenal perburuhan sebagai sekarang. Cara produksmja kecil-kecil, wataknja kolot, kuno, tidak kenal cara sopan, menghantam, monopoli dan kekerasan dan kekedjaman. Sistem paksa dimana-mana, menghantjurkan keradjaan dengan kekerasan sendjata. Cultuurstelsel jang sebagai tjambuk djatuh diatas pundak dan belakangnja rakjat. Lambat-laun, dimasa modernkapitalisme mengganti kapitalisme jang tua bangka. Pabrik-pabrik, bankbank, pelabuhan-pelabuhan, kota-kota industri timbullah seakan-akan djamur dimusim dingin (DBR, 1964.263),

g. Kapitalisme modern menunjukkan kemodernan jang hebat sekali, tempat-tempat pekerjaan jang ramainja menulikan telinga, pabrik-pabrik jang asapnja menggelapkan angkasa, bank-bank jang tingginja mentjakar langit, perburuhan jang memakai ribuan, ketian kaum proletar (DBR, 1964:262).

h. Dan bukan sadja bermulut sepuluh. Djalannja mentjari rezeki bukan satu djalan sadja, tapi djalan jang bertjabang-tjabang tiga, empat. Bukan lagi Indonesia hanja mendjadi tempat pengambilan barang biasa sebagai dizamannja imperialisme-tua. Bukan hanja mendjadi tempat pengambilan pala, tjengkeh, meritja, kaju manis tapi mendjadi pasar pendjualan barang-barang keluarannja kepabrikan negeri asing. Mendjadi tempat penanaman modal asing: pabrik-pabrik gula ratusan, onderneming teh, karet, kopi, tembakau penjelmaan modal asing dibuka dimana-mana, tersebar kesemua djurusan (DBR, 1964:264-265).

i. Bandjir harta jang keluar dari Indonesia bukan semakin surut malahan makin besar, drainase Indonesia makin makan. Kaum Marhaen 
merasakan kepapaan dan kesengsaraan, saban hari, saban djam, saban menit kekurangan segala-galanja, kekurangan bekal hidup, kekurangan pakaian, kekurangan bekal pendidikan anaknja (DBR 1964:270). Kang Marhaen hidupnja megap-megap, keliwat-mlarat, hidup sebenggol sehari. O, Marhaen hidupmu sehari-hari morat-marit dan kotjar-katjir. Kerusakan lahir. Di zaman air mata ini Marhaen di tanah Djawa masih harus memelihara juga hidupnja ribuan orang kuli kontrakan, jang dipulangkan dari Deli dan lain sebagainja zonder tundjangan sepeserpun jua. "Habis manis sepah dibuang" (DBR, 1964:273).

Dengan maksud memberikan efek perlawanan maka Bung Karno menganalogikan kapitalis yang imperialis-kolonialis itu dengan kata benda kongkret dan hidup, yaitu kata Rahwana Dasamuka yang bermulud sepuluh. Penggunakan kata rahwana dasamuka pembaca dapat memahami makna kontekstualnya dengan cara bottom-up processing, "scenario “, Co-text”. Dengan memanfaatkan kata-kata seperti tersebut dapatlah dipahami bahwa medan wacana retorika bahasa Bung Karno relatif tidak menyimpang dari masalah Kolonialisme dan Imperialisme sebagai akibat sistem ekonomi kapitalis-Iiberalis yang dibawa dan diawali oleh pemerintahan asing-Belanda di Indonesia. Dengan motif tersebut maka masuk akal jika Bung Karno melakukan perlawanan dengan retorika yang antara lain berkomponen kata benda yang berkonotasi dan berefek dua hal, yaitu ke luar dapat membenci dan memusuhi sistem kapitalis dan penyebarnya, ke dalam dapat berefek membentuk character building dan nation building.

Kata yang dimanfaatkan dalam praktik wacana RRD, ada pula yang berupa penamaan atau penyebutan. Artinya, Bung Karno menamainya atau menyebutnya. Oleh karena retorikanya sebagai praktik wacana terlembagakan dalam bentuk teks dan monolog maka Bung Karno sebagai penulis atau pengarang memiliki keleluasaan bahkan kewenangan untuk menamai atau menyebut dengan kata-kata tertentu terhadap orang, tokoh, faham tertentu dan kelompok tertentu. Dalam hal penamaan atau penyebutan tersebut dapat dibedakan antara mereka yang diposisikan atau dikategorikan sebagai lawan/musuh dengan mereka yang dikategorikan sebagai kawan. 
Penamaan atau Penyebutan terhadap Lawan/Musuh dan Kawan/Kita

\begin{tabular}{|c|c|c|c|c|}
\hline NO & LAWAN/MUSUH & HLM & KITA/KAWAN & HLM \\
\hline 1. & Feodalisme kuno & 262 & Kaum tertindas & 15,16 \\
\hline 2. & Feodalisme baru & 262 & Kaum mlarat & 15,16 \\
\hline 3. & Kaum yang memerintah & 41 & Kaum kebangsaan & 19 \\
\hline 4. & Fihak itu & 52 & Kaum keagamaan & 19 \\
\hline 5. & Kaum modal Belanda & 54 & Kaum proletar & 19 \\
\hline 6. & Kapitalisme kepabrikan & 256 & Kaum Manris & 14 \\
\hline 7. & Kapitalisme pertanian & 256 & Kaum Pan-Islam & 54,65 \\
\hline 8. & Kapitalisme & $\begin{array}{l}60,94, \\
124,187\end{array}$ & Ibu Indonesia & $\begin{array}{l}22,42,63 \\
79,110 \\
112,169 \\
\end{array}$ \\
\hline 9. & Kaum kuasa & 63 & Mahatma persatuan & 22 \\
\hline 10. & Imperialisme bahan mentah & 215 & HOS Tjokroaminoto & 22 \\
\hline 11. & $\begin{array}{l}\text { Imperialisme penanaman } \\
\text { modal }\end{array}$ & 215 & Tjipto Mangunkusumo & $22,41,66$ \\
\hline 12. & Imperialisme industrialisme & 231 & Samaun & 22 \\
\hline 13. & Imperialisme ekonomi & 239 & Kampium persatuan & 22 \\
\hline 14. & Imperialisme barat & 240 & Hadji Agus Salim & 209 \\
\hline 15. & Imperialisme Japan & 240 & M. Hatta & $\begin{array}{l}63,87 \\
207 \\
\end{array}$ \\
\hline 16 & Imperialisme Inggris & 129 & Kita, abdi, hamba & 76,110 \\
\hline 17. & Imperalisme internasional & 264 & Kaum si kulit berwarna & 83,85 \\
\hline 18. & Imperialisme tua, modrn & 263 & Badan bumiputra & 84 \\
\hline 19. & Imperialisme dahaga & 276 & Si kaum sini & 84 \\
\hline 20. & Imperialisme kulturstelsel & 258 & Kaum kita & 84 \\
\hline 21. & Imperialisme kultur & $\mathrm{T} 58$ & Kaum sosialis internasional & 95 \\
\hline 22. & Imperialisme raksasa & 261 & Kaum bapak, kaum ibu & 99 \\
\hline 23. & imperialisme tua bangka & 261 & Kaum perempuan & 100 \\
\hline 24. & Imperialisme eksploitasi & 129 & $\begin{array}{l}\text { Indonesia piatu sudah } \\
\text { beribu kembali }\end{array}$ & 107 \\
\hline 25. & Imperialisme tjampuran & 146 & Kaum sabar, kaum keras, & 109 \\
\hline 26. & Imperialisme ortodok & 150 & Kaum bawahan & 143 \\
\hline \multirow[b]{2}{*}{28.} & $\begin{array}{l}\text { Stelsel blorong yang } \\
\text { batinnya berisi racun }\end{array}$ & 243 & $\begin{array}{l}\text { Masyarakat merek ketjil } \\
\text { merek kromo, merek } \\
\text { marhaen }\end{array}$ & \multirow{2}{*}{$\begin{array}{l}152 \\
152\end{array}$} \\
\hline & Raksasa dasamuka & $\begin{array}{l}77,146,1 \\
56,264,2 \\
85,295 \\
\end{array}$ & $\begin{array}{l}\text { Kaum saudagar Kaum } \\
\text { pelayar Kaum perantau }\end{array}$ & \\
\hline 29. & Barisan sikulit putih & 84 & Kaum produsen bumiputra & 152 \\
\hline 30. & Kaum industri gemuk & 142 & $\begin{array}{l}\text { Kang Marhaen, Mbok } \\
\text { Marhaen }\end{array}$ & 270 \\
\hline 31. & Kaum atasan & $\mathrm{S} 43$ & Kaum Marhaen Indonesia & 168 \\
\hline
\end{tabular}




\begin{tabular}{|c|c|c|c|c|}
\hline 32. & Direktur BB & 177.109 & Indonesia muda & 100 \\
\hline 33. & Kaum pendjadjah & 178 & Kaum terdjadjah & 178 \\
\hline 34. & Kaum kolonisator & 178 & Kaum gekoloniseerde & 178 \\
\hline 35. & Selama masih ada kaum sana & 195 & Menduduki pundak sini & 195 \\
\hline 36. & $\begin{array}{l}\text { Kaum madjikan merengut, } \\
\text { Kaum madjikan tidak } \\
\text { merengut. } \\
\text { Kaum madjikan memisuh } \\
\end{array}$ & 234 & $\begin{array}{l}\text { Golongan kaum ningrat } \\
\text { Golongan kaum djempolan } \\
\text { Masyarakat feodal }\end{array}$ & 171 \\
\hline 37. & Antitese antara sana dan sini & 200 & Kaum radikal & 193 \\
\hline 38. & $\begin{array}{l}\text { Mendalamkan antara sana } \\
\text { dan sini }\end{array}$ & 200 & Kaum pergerakan & 195 \\
\hline 39. & \begin{tabular}{|l|} 
Antara sana dan sini ada \\
pertentangan sebagai Api dan \\
air Srigala dan rusa \\
Kedjahatan dan kebenaran
\end{tabular} & 289 & $\begin{array}{l}\text { Menggodok kaum } \\
\text { perempuan bersama kaum } \\
\text { laki-laki dalam satu kawah } \\
\text { tjandradimukanja } \\
\text { perdjoangan melawan } \\
\text { stelsel kemodalan }\end{array}$ & 247 \\
\hline 40 & $\begin{array}{l}\text { Pertentangan dua golngan } \\
\text { Golongan atas dan bawah } \\
\text { Zaman feodal gol. ningrat } \\
\text { dengan gol. Kawulo Zaman } \\
\text { kapitalis gol.kemodalan } \\
\text { dengan gol.proletar Zaman } \\
\text { kolonial gol.sipendjadjah } \\
\text { dgn gol. siterdjadjah }\end{array}$ & 1289 & $\begin{array}{l}\text { Sana dan sini selamanja } \\
\text { bertabrakan sebagai singa } \\
\text { dan mangsanja. Tidak ada } \\
\text { perbarengan, persamaan, } \\
\text { persesuaian antara sana dan } \\
\text { sini }\end{array}$ & 1290 \\
\hline
\end{tabular}

Sebutan atau penamaan sebagaimana terdapat dalam tabel tersebut mencerminkan proses pengkategorian antara kita sebagai kawan senasib dan seperjuangan dengan mereka sebagai lawan atau musuh yang harus dibenci dan disingkirkan. Bung Karno sebagai salah satu motor pergerakan kebangsaan Indonesia ingin membangun masyarakat majemuk yang tereksploitasi, baik ekonomi, politik maupun sosial untuk bangkit berjuang demi mencapai kemerdekaan. Sedangkan pelibat praktik wacana dalam retorikanya berkisar antara elit politik pergerakan berkomunikasi dengan masyarakat majemuk terjajah tentang sistem ekonomi-politik yang mengeksploitasinya. Elit politik pergerakan tercermin dalam diri Bung Karno. Ia merupakan pengejawantahan nilai-nilai ideal dan nilainilai tersebut terartikulasikan ke dalam bahasanya, termasuk kata-kata yang digunakan dalam wacana RRD. Nilai-nilai yang terbawa atau tercakup dalam katakata itulah yang dimanfatkan untuk melakukan praktik menata ulang kognisi, afeksi 
dan psikomotor masyarakat majemuk. Tujuannya melawan RRD ekuivalen ideologi kapitalis-imperialis. Jadi, Bung Karno sebagai komunikator atau "narator" dapat memposisikan kapitalisme dan imperialisme sebagai aktor atau pelaku perbuatan, sedangkan masyarakat majemuk terjajah dapat diposisikan sebagai objek atau korban penderita karena perbuatannya. Aktor sebagai penyebab yang mengakibatkan masyarakat majemuk terjajah menjadi korban, baik ekonomi, politik maupun sosialnya. Penderitaan yang berkepanjangan itulah yang cenderung menjadi "amunisi" bagi Bung Karno dalam proses penggalian dan pemilihan "peluru" kosakata untuk tujuan melawannya.

Kata-kata yang dipilih merupakan salah satu sarana wacana yang ditugasi untuk melakukan perlawanan terhapap sistem ekonomi kapitalis-imperialis. Perlawanannya tentu tidak secara fisik, tetapi dengan menggali dan memilih bentuk dan makna kata yang berdaya fugsional-kontekstual dalam membangun masyarakat baru yang berkarakter nasionalis-patriotis sebagai bekal melawannya dan mendirikan negara-bangsa yang merdeka.

Wacana RRD dalam tulisan Bung Karno bukan sekedar seseorang mengatakan satuan makna dan informasi kepada publik pembaca. Wacana RRD berposisi sebagai teknik dan strategi tuturan verbal atau linguistik untuk tujuan melakukan tindakan politis dalam bahasa. Kata-kata dan gaya bahasanya berdimensi mampu nenuntut pelaksanaan perlawanan, misalnya membenci, memusuhi lawanlawan politiknya, terutama RRD ekuivalen penjajah Belanda. Kata-kata dan gaya bahasa dalam wacana RRD seperti memiliki kompetensi, status ilmiah dan otoritas sehingga mudah diikuti dan dilaksanakan oleh masyarakat pembacanya.

Penggunaan bahasa dalam wacana RRD mencerminkan kemampuan penulisnya dalam berimajinasi, berpikir kritis, kreatif terhadap konteks situasi dan keterjadian pada masa pergerakan. Bung Karno sebagai penulisnya melakukan komunikasi politik kepada publik dengan memanfaatkan kata-kata yang ada, tetapi dengan perspektif makna dan pesan yang baru sesuai dengan motif dan tujuannya. Penggunaan kata-kata dan gaya bahasa yang visioner sehingga gambaran realitas masa depan rasional benar-benar tergambar jelas dalam benak pembaca atau pendengarnya. Dengan demikian, retorikanya berpotensi fungsional 
mentransformasi kognisi, afeksi dan psikomotor pembaca dan pendengarnya ke arah yang baru sesuai dengan tujuannya.

\section{Simpulan}

Dalam tulisannya, Bung Karno lebih dominan berbicara Raksasa Rahwana Dasamuka daripada Kapitalisme-Imperialisme. Praktik wacana dengan retorika persuasif yang mempersonifikasikan wacana RRD. Sistem ekonomi dan sistem berpikir (Kapitalisme-Liberalisme) dipersepsikan sebagai makhluk hidup yang berwatak serakah. Pembaca didikte, dikontrol, didominasi dan dikendalikan kognisi, afeksi dan psikomotornya ke arah "buto" raksasa serakah tersebut.

Bahasanya bertugas medefinisikannya: siapa Dasamuka, bagaimana ia berproses menjadi raksasa, bagaimana postur dan gesturnya, watak dan tingkah lakunya terhadap bangsa dan tanah air Indonesia. Bagaimana kondisi bangsa dan tanah air kita sebagai akibat perilaku RRD, dan bagaimana seharusnya untuk melawannya. Cara pendefinisian secara retorik ideologis.

Wacana dan bahasanya seperti "bel komando" yang membuat individuindividu rela mengeliminasi dan menetralisasi ekspresi gerak jiwa dan fisik yang tidak bernilai guna politik, ekonomi dan sosial.

\section{Daftar Pustaka}

Dardjowidjojo, Soenjono. 1991. “Pemerolehan Foiplogi dan Semantik pada Anak: Kaitannya dengan Penderita Afasia." Soenjono Dardjowidjojo (Penyunting). PELLBA 4. Yogyakarta: Kanisius.

Eriyanto. 2001. Analisis Wacana Pengantar Analisis Teks Media. Yogyakarta: LkiS.

Faucault, Michel. 1972. The Archeologi of Knowledge (Arkeologi Pengetahuan). 2002. Penerjemah H.M. Mochtar Zoenii. Yogyakarta: Qalam.

Geertz, Glifford. 1974. The Interpretation of Cultures: Selected Essays (Kebudayaan dan Agama). 1992. Penerjemah Francisco Budi Hardiman. Yogyakarta: Kanisius.

Halliday, M.A.K. and Ruqaya Hasan. 1985. Language, Context and Text: Aspects of Language in a Social-Semiotic Perspective (Bahasa, Konteks dan Teks: Aspek-Aspek Bahasa dalam Pandangan Semiotik Sosial). 1992. Penerjemah Asrudin Barori Tou. Yogyakarta: Gadjali Mada University Press. 
Hidayat, Komaruddin. 1996. Memahami Bahasa Agama Sebuah Kajian Hermeneutik. Jakarta: Paramadina.

Djajasudarma, T.Fatimah. 1994. Wacana Pemahaman dan Hubungan Antarunsur. Bandung: PT. Eresco.

Kartomihardjo, Soeseno. 1993. "Analisis Wacana dengan Penerapannya pada Beberapa Wacana." Bambang Kaswanti Purwo (Penyunting). PELLBA 6. Yogyakarta: Kanisius.

Keraf, Gorys. 1992. a. Argumentasi dan Narasi. Jakarta: Gramedia Pustaka Utama. Muhadjir, H. Onoeng. 1996. Metodologi Penelitian Kualitatif. Yogyakarta. Rake Sarasin.

Moleong, Lexy J. 2002. Metodologi Penelitian Kualitatif. Bandung. Remaja Rosdakarya.

Nimmo, Dan. Political Communication and Publik Opinion in America (Komunikasi Politik: Komunikator, Pesan dan Media). 1993 Penerjemah Tjun Surjaman. Bandung: Remaja Rosdakarya.

Oetomo, Dede. 1993. "Pelahiran dan Perkembangan Analisis Wacana." Bambang Kaswanti Purwo (Penyunting). PELLBA 6. Yogyakarta: Kanisius.

Purwo, Bambang Kaswanti. 1989. Pragmatik dan Pengajaran Bahasa Menyibak Kurikulum 1984. Yogyakarta: Kanisius.

Purwasito, Andrik. 2002. Imajeri India Studi Tanda Wacana, Surakarta: Pustaka Cakra.

1992. d. Retorika Modern Pendekatan Praktis. Bandung: PT. Rosdakarya.

Ricoeur, Paul. The Interpretanon Theory: Discourse and the Surplus of Meaning (Filsafat Wacana Membelah Makna dalam Anatomi Bahasa). 2002. Penerjemah Musnur Hery. Yogyakarta: IRCiSoD.

Sukarno. a. Dibawah Bendera Revolusi. Jilid Pertama. Cetakan Ketiga. Tahun 1964. Panitia Penerbit H.Mualliff Nasution. 